\title{
Vulnerability, Risk and Agroterrorism: An Examination of International Strategy and its Relevance for the Republic of Korea
}

\author{
Stephen Green, Tom Ellis, Jeyong Jung \& Julak Lee
}

\author{
Institute of Criminal Justice Studies, University of Portsmouth
}

\begin{abstract}
This article explores the under-researched subject of agroterrorism, and how this is being addressed in the Republic of Korea (South Korea). It first outlines the differences between bio-terrorism, food terrorism and agroterrorism and why it is becoming increasingly important to focus on risks to farming and the food chain. The article then explores a range of international models of organisational structures and processes designed to counter agroterrorism in the USA, Australia and UK, based on an analysis of all available open source materials at the time of writing. This provides a critical picture of the understanding of risk, security \& preparedness in those three countries against which the South Korean model can be compared. We found that, compared to the mature arrangements in place in the USA and Australia, both the UK and the Republic of Korea have relatively immature strategies to protect farmers, food production and rural communities, focussing only on maintaining alternative safe food sources for consumers. These relatively weak policies essentially ignore the potentially significant social and economic impact of agroterrorism. We conclude by proposing further research, including fieldwork with local communities in the agricultural sector, including first responders, within South Korea. Overall, these findings may help Korean policy makers to consider their current approach within an international perspective and encourage them to consider both national resilience and local interests.
\end{abstract}

\section{Introduction}

This article examines key international models for countering or responding to the risk of agroterrorism. It compares current policies, structures and levels of preparedness in: Australia; the USA; and UK with those of the Republic of Korea (RoK: more widely known as South Korea).

The article begins by defining agroterrorism, placing it in context on the spectrum of all terrorism activity, and examining why there is a need in some countries for greater focus on protecting the food chain in general, and farming in particular, as an important element of the national infrastructure. We introduce some notable international and regional examples of security and safety issues caused by problems related to the food chain and how these might be relevant to the framing of food and agroterrorism. Next, through reviewing publications from disparate national and international sources, we illustrate the variety of counter-agroterrorism strategies adopted around the world, to allow comparison of the RoK model. We will see that this compares relatively poorly to 
the seemingly more coherent US and Australian approaches, but resonates with aspects of the "light touch" approach being taken currently in the UK. Lastly, we suggest proposals for subsequent research in RoK, which are adapted from the ongoing research that we are carrying out in the UK and which would also provide a further level of comparability. This research approach focuses on local agricultural communities and those who are in the frontline as local first responders to agroterrorism. We will argue that their knowledge and perceptions of the problem will be vital for effective prevention, detection and response. Overall, these findings may help RoK policy makers to consider their current approach within an international, comparative perspective and ensure they better address both national resilience and local community interests. 


\section{What is agroterrorism?}

Within terrorism studies, bioterrorism has for some time been widely used as a term to define the offensive use by politically-motivated actors of biological agents to cause harm. However, bioterrorism is not necessarily food related. As shown in Figure 1, food terrorism, then, can be seen as a subset of bioterrorism, involving deliberate contamination of food to cause direct harm, as in the Chinese/Japanese gyoza example outlined below. But agroterrorism ${ }^{1}$ has a more specific focus yet, and relates only to action against primary food production. It has been defined as "the deliberate introduction of a disease agent, either against livestock or into the food chain, for purposes of undermining socioeconomic stability and/or generating fear" (Chalk, 2004). The use of the term "agent" can also cause confusion, in that it can relate to biological pathogens such as viruses, parasites, fungi or bacteria, but also to non-biological toxins such as Ricin. Since bioterrorism and agroterrorism are so often confused (Ungerer \& Rogers, 2006), Figure 2 below outlines the main distinctions and perhaps indicates the relative ease with which agroterrorism can be carried out and the greater

Figure 1: Typology of terrorism

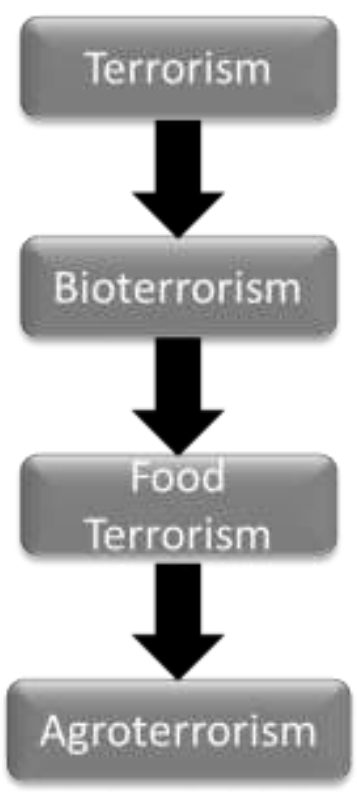
potential damage it can cause.

Figure 2: Key differentiations between Bioterrorism and Agroterrorism

\section{Bioterrorism}

(directed at humans)

- Requires considerable technical expertise to weaponise agents

- is exceedingly hazardous for the perpetrator

- is inefficient in large, open spaces

- is unlikely to cause significant long term economic damage

- but is a dread risk

(Derived from Stern, 2003)

\section{Agroterrorism}

(directed at animals and crops)

- Low tech, high impact

- is safe for perpetrator (if the agent selected is non-zoonotic)

- is most effective against animals

- is difficult to differentiate from natural outbreaks

- can cause huge social and economic cost

- but is largely unrecognised in many by the public and farming industry in some countries

(Derived from Wheelis, Casagrande \& Madden, 2002)

A number of factors contribute to the vulnerability of modern agriculture to terrorist action, including:

- Greater intensification

- Geographical \& operational concentration

- Long term, insecure storage

- Multimodal logistics

${ }^{1}$ Confusingly, also known as Agricultural bioterrorism (Kosal \& Anderson, 2004); and Agriterrorism (Hinrichs, 2013, p9). 
- Reduced isolation - ready availability of foreign pathogenic material

- Reliance on artificial pest control

- Lack of genetic diversity

- Commercial reluctance to use vaccination

- Disease eradication programs that will inevitably reduce natural resistance to specific pathogens

(Foxell, 2001. Nganje, Wilson \& Nolan 2004)

However, just because something is vulnerable does not mean it is at significant risk. Risk is the product of the likelihood and resultant impact of an adverse event. Likelihood results in part from the attractiveness of an asset to an adversary, which is influenced by perceived vulnerability. However, most importantly, assessment of risk is entirely subjective, in the "eye of the assessor". This leads to differences in mitigation strategies for what appear ostensibly to be identical risks. Over the last twenty years, agroterrorism has received increasing amounts of international attention, but the counter-measures put in place across the globe differ markedly. The policies and practices of the USA, Australia, UK and RoK are examined in this article. Additionally, Europe (Martensson et al, 2013) and Russia (Golikov, 2009) are also developing their own distinctive approaches.

What all of these approaches have in common is that they all see the food chain as a continuum, from upstream primary production (agriculture and associated industries), to downstream food preparation, distribution and marketing (British Standards Institute, 2014, p2). Figure 3 outlines the key elements involved from upstream to downstream. Whilst the strategies of many countries addresses the whole food chain, by definition agroterrorism naturally affects directly those sectors to the left hand side of this diagram, as illustrated by the dashed box.

Figure 3: The food supply web (from PAS96:2014)

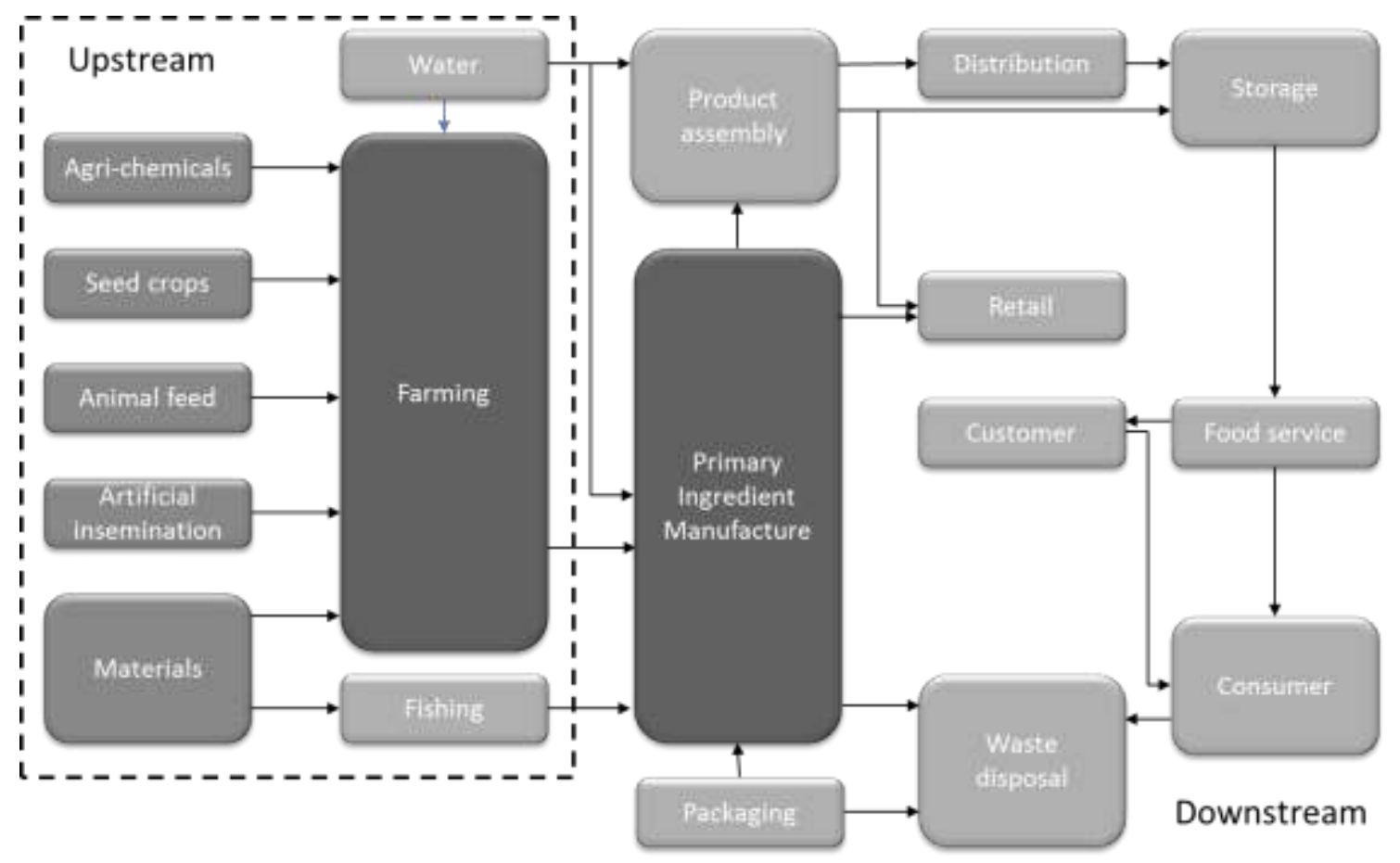

It can be argued that as a modern developed society RoK should be among the growing number of nations addressing the issue seriously. Having established the key concepts of agroterrorism and 
how it sits within the wider field of bioterrorism, we will now examine why this subject has any relevance to Rok.

\section{Relevance to RoK security?}

In the summer of 2008, mass rallies in RoK against US beef imports made international news for several days running. Video footage and reports of tens of thousands demonstrating in Seoul Plaza for 2 months in the summer heat showed how one relatively benign food issue could seriously impact political and social stability. Some commentators even suggested that these "beef riots" undermined the recently-elected Lee Myung-bak government.

Despite this, when President Park Geun-hye argued that 'unsafe food' was one of the four main social evils that needed eradicating (along with sexual violence, domestic violence and school violence) she was ridiculed in some quarters and political opponents downplayed food safety compared to the seriousness of the other three issues. (Kim, 2013). However, Kim (2013) observed that as a politician, she had recognised the deep public concern over food safety issues and continued to associate them with national security, although the focus was still mainly on unlawful, non-terrorist acts in the food industry (Kim, 2013).

This is unsurprising in a country that rates its food quality so highly, where contamination cases receive enormous media coverage and severe penalties. Lee Gwang-bok, CEO of Dongsuh Food, along with four associates, became the first CEO of a major food company to be charged in Korea for knowingly selling contaminated cereal. Dongush Food had mixed 42 tons of older cereal, already infected with coliform bacteria, with new cereal. The resultant products were subsequently sold in April and May 2012 for some 2.8 billion ( $\$ 2.5$ million) (Jung, 2014). This violated the 2008 Korean law requiring food companies to conduct regular checks and to notify Ministry of Food and Drug Safety (MFDS) of problems and recall products. It also violated the internationally-established Hazard Analysis Critical Control Point (HACCP) manufacturing quality assurance requirements.

The case is salutary in trying to identify the motives for food contamination. While the motive here was essentially financial, it was not a simple attempt at fraud. It could be argued, especially by defence lawyers, that in such cases there was no direct malicious motive. Instead, use of cheaper substances to adulterate more expensive ones would be seen as an acceptable way of increasing profits. Use of substandard, out-of-date, diluted and/or contaminated food products might cause health problems, but this would be seen as potential, unfortunate side-effect for the fraudster taking a risk, and who, ideally, does not wish to provoke investigative attention. Such a cultural mind-set was revealed when Dongsuh Food argued that it had "...only contaminated $10 \%$ of the cereals it sold" (Jung, 2014).

In some cases, even though contamination is accidental, the simple cost of destroying unwittingly infected food products provides sufficient motive to cover up the incident. Across the Korea Strait, in 2011, at the consumer end of the food continuum in Japan, five people died and many more were made critically ill after eating contaminated raw Japanese beef in different branches of one national chain restaurant. In a subsequent investigation, it was found that the chain had flouted state health and safety regulations consistently for at least two years (O'Shea, 2015). In another infamous regional case, we see something more recognisable as deliberate food terrorism at the point of 
distribution. In this incident a worker in Hebei, China reacted to poor working conditions in his factory by deliberately injecting harmful pesticides into some bags of frozen gyoza (dumplings). Some of these were exported to Japan, where ten people fell ill (O'Shea, 2015).

In these two Japanese cases, the political results were quite different, revealing an ingrained social/cultural bias. The Japanese concept of "kokusan" is equivalent to the Korean concept of "kuk$s^{\prime \prime}$ ", in that domestically produced food is valued more highly than foreign food for quality and expected health and safety guarantees. This allows space for what O'Malley (2004 p.7) and O'Shea (2015 p. 304) call the risk and governmentality approach, which leads to the politicisation of risks associated with food contamination. Perceptions of risk, as well as the risks themselves, can have powerful consequences and have to be predicted and managed. The combination of foreign food and deliberate contamination in the Japanese gyoza incident, despite the lack of fatalities, produced a national outcry, mass hysteria, and calls for a ban on Chinese food imports ( $O^{\prime}$ Shea, 2015). In this sense, kuk-san may be seen as a catalyst for the magnitude of the 2008 RoK beef riots, inflaming an already tense political situation.

Conversely, in the domestic, but accidental, raw beef contamination incident, despite being the deadliest food contamination case in Japan since the 1990s, the reaction was very different and politically far less difficult to manage. The risk in this case was perceived as being personal, and there was a mixed reaction from industry, media, and consumers, many of whom called for the government to allow citizens self-responsibility to mediate their own risks for Japanese-produced food. As O'Shea (2015) notes, behavioural sciences can tell us important things about risk, but the political and international context is also a factor to be considered when assessing the likely scale of impact from agroterrorism.

It can be argued that historical, accidental cases such as: those above; the 2001 Foot \& Mouth Disease outbreak in the UK; and an earlier one in Taiwan in 1997, bring into question the world's preparedness for deliberate, malevolent, multi-site attack on the global agriculture industry. There are several factors which support this pessimistic view of vulnerability. The current and increasing trends in agriculture are for larger farm sizes and greater centralisation of resources, creating higher efficiency to meet the "neo-productivist" view of a commercially resilient supply (Kirwan \& Maye, 2013, p94), supporting a "Just in Time" model of modern supermarket logistics. This, however, creates a potential "boomerang effect" (Beck, 1992, p23) of increased security vulnerability through systemic complexity (Perrow, cited in Borodzicz, 2005, pp30-31). Given the fact that many countries' governmental contingency arrangements have never been tested against a deliberate and widespread attack, the statement of the newly-appointed head of the UK Countryside Agency in 2008 that the UK is "only nine meals away from anarchy" (Boycott, 2008, p1) is sobering. This gloomy view resonates with President Park Geun-hye's view that the food chain must be considered as part of RoK Critical National Infrastructure (CNI). But whilst Peck (2006, pp18-19) notes that the food chain is uniquely open to a wide set of ideologically-motivated threats aimed at causing death, injury and financial damage to business and the nation, the perception of this risk differs across the globe. The next section explores the wide variance of risk mitigation models adopted across the globe, often by countries that have ostensibly similar agricultural industries. 


\section{Mapping responses to agroterrorism: an international comparative perspective}

In researching this topic, it quickly became obvious that despite the growing interest and treatment of agroterrorism across the globe, it is an under-researched area in terms of mapping domestic and international strategy, policy and organisational landscapes addressing agroterrorism. An in-depth documentary analysis showed that there is no single, "go to" source of information available in any country which outlines and explains the legislative and organisational structure designed to mitigate the specific risk of agroterrorism.

Information therefore had to be sought from across many departmental and policy boundaries, including:

- Agriculture

- Security

- Public

- Animal and Plant Health

- Food Safety

- National Resilience

The analysis and diagrams presented here have thus been produced by synthesising publications from a variety of levels, from official documents, through 'grey' papers, to academic sources. Below, we represent the organisational structures of the USA in Figure 4, followed by a brief discussion of its strengths and weaknesses in combating agroterrorism. The same is then done for Australia (Figure 5) and the UK (Figure 6). We then examine critically the development of similar policies and processes in RoK (Figure 7) and suggest ways that this should be improved.

\section{The US model}

Food chain vulnerability was recognised in the USA as long ago as the 1990s, prior to the 9/11 attack and the subsequent Homeland Security Act of 2002. However, following the events of 2001, new funding was provided against a series of Homeland Security Presidential Directives which mandated action in regard to explicit food chain elements within the overall CNI protection mechanism. In addition, early detection of agroterrorism was the focus of a 2013 Government Accountability Office report, which proposed a controversial "Big Data" approach to whole population animal health monitoring (GAO, 2013). 


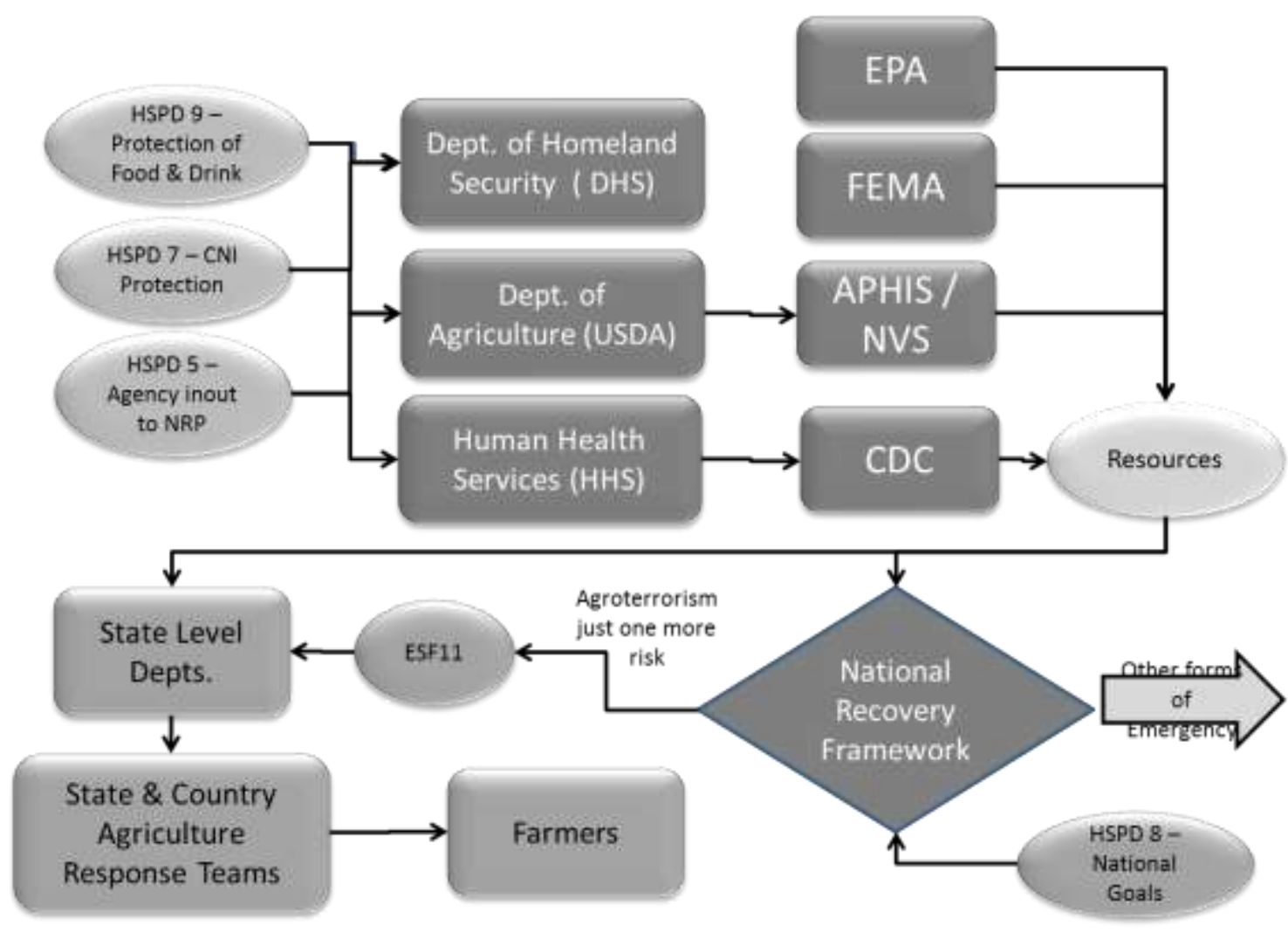

As Figure 4 shows, the inclusion of agroterrorism considerations within the wider overall Homeland Security structure meant that the need for involvement at grass root levels had been understood. In by far the most comprehensive set of counter-agroterror measures seen in the western world, US state and county level Agriculture Response Teams were created to disseminate information, and universities now offer courses in agroterrorism to first responders. However, as with all risk management approaches, residual weaknesses inevitably remain. The US model, for example, struggles to differentiate at an early stage between an accidental outbreak, which requires action only from the department of agriculture (USDA) and a deliberate attack requiring additional action from law enforcement and Department of Homeland Security (DHS) resources. The conflict between containment and restoration by USDA, and investigation and evidence gathering by law enforcement is recognised and being addressed through scenario-based exercises to resolve effective pathways locally. 


\section{The Australian model}

Australia is similar to the USA in that it has a federalised governmental system and takes an interdisciplinary approach to countering agroterrorism. However, as Figure 5 shows, the key difference is that whilst the USA concentrates on early detection and rapid response to events on farm, the Australian Dept. of Agriculture, Fisheries and Forestry (DAFF) puts maximum effort into enforcing strict border quarantine standards to maintain their treasured disease free status. This is logical, as Australia has no land borders across which contamination can occur naturally, so securing the sea and air borders will intrinsically protect the interior of the country.

Figure 5: Australian organisational processes to combat agroterrorism

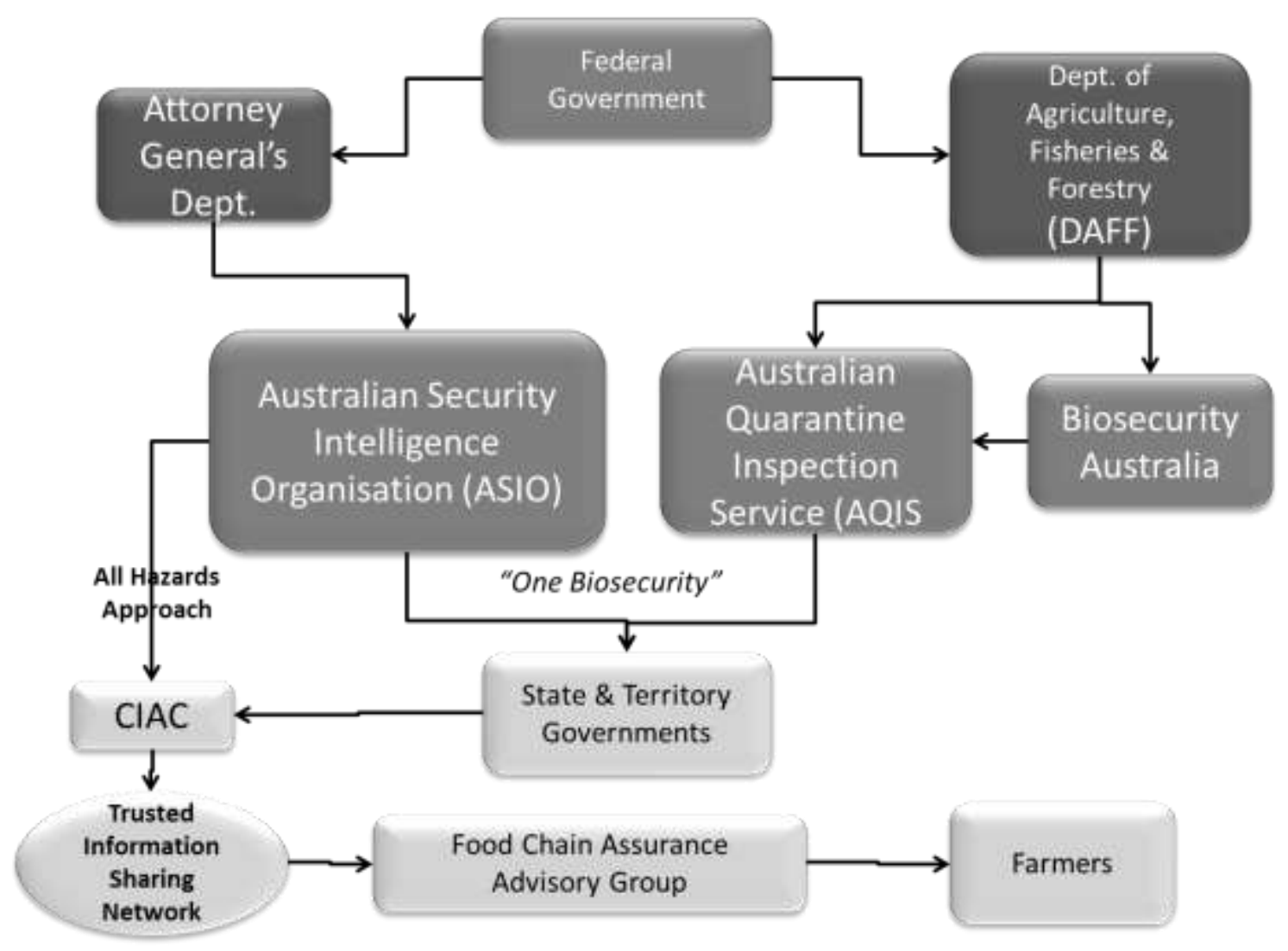

The Australian "All hazards" approach resonates with the US approach (and that now being adopted in the UK) in that agroterrorism is incorporated as just one more factor within a broader risk landscape. Information on threats and vulnerabilities is distributed through a common platform called the Trusted Information Sharing Network (TISN) under control of the Critical Infrastructure Advisory Council and operating right down to local Food Chain Assurance Advisory Groups and the food industry. This model of intervention allows Biosecurity Australia to advise the Australian Quarantine Inspection Service (AQIS) on the evolution of natural threats, while ASIO (Australian Intelligence) advise on criminal or security threats. Crucially, both provide advice to local states and territories (which each have their own laws and regulations aligned to national legislation) within the same strategic model.

\section{The UK model}

The UK model, like that of Australia, now adopts an "All Risk" approach to countering agroterrorism, which includes elements of: 
- Food safety through the Food Standards Agency (FSA) and it's devolved equivalents

- National resilience through the Civil Contingency Secretariat (CCS)

- Security and Intelligence through the Security Services and the National Counter-Terrorism Security Office (NaCTSO)

However, the lead Government Department for all agriculture matters remains the Department for Environment, Food \& Rural Affairs (DEFRA). DEFRA and FSA have taken over responsibility for the protection of the food chain with the latest revision of a Publicly Available Specification, PAS96:2014, entitled "Guide to protecting and defending food and drink from deliberate attack". This new iteration of the standard moves away from the quasi-military, triage-like approach of the previous 2008 and 2010 versions, which notably were sponsored by security agencies, towards a more civilian-friendly risk management process closely aligned with existing food safety legislation. However this change of ownership, coupled to the fact that, as first highlighted by Byrne in 2009, there is still no mention of terrorism on either DEFRA or FSA websites, may suggest a dilution of effort to counter this small, but significant, risk. The concern is that DEFRA may be out of touch with upstream producers, whose views were reflected in Peck's $(2006, p, 58)$ findings from UK Food \& Drink Industry's business continuity managers that "...terrorist attack on the food chain resulting in consumer deaths was the scenario that some quality managers privately feared the most".

PAS96:2014 sets out a Threat Analysis Critical Control Point (TACCP) approach to countering agroterrorism. TACCP is a risk management process that identifies vulnerabilities at specific points along products' 'farm to fork' lifecycle. It is based on the well-established HACCP food quality assurance methodology, familiar to the food industry, recommended by FSA and Local Authority Trading Standards officers, and which in turn aligns with World Health Organisation advice (WHO, 2002). 
Figure 6: UK organisational processes to combat agroterrorism

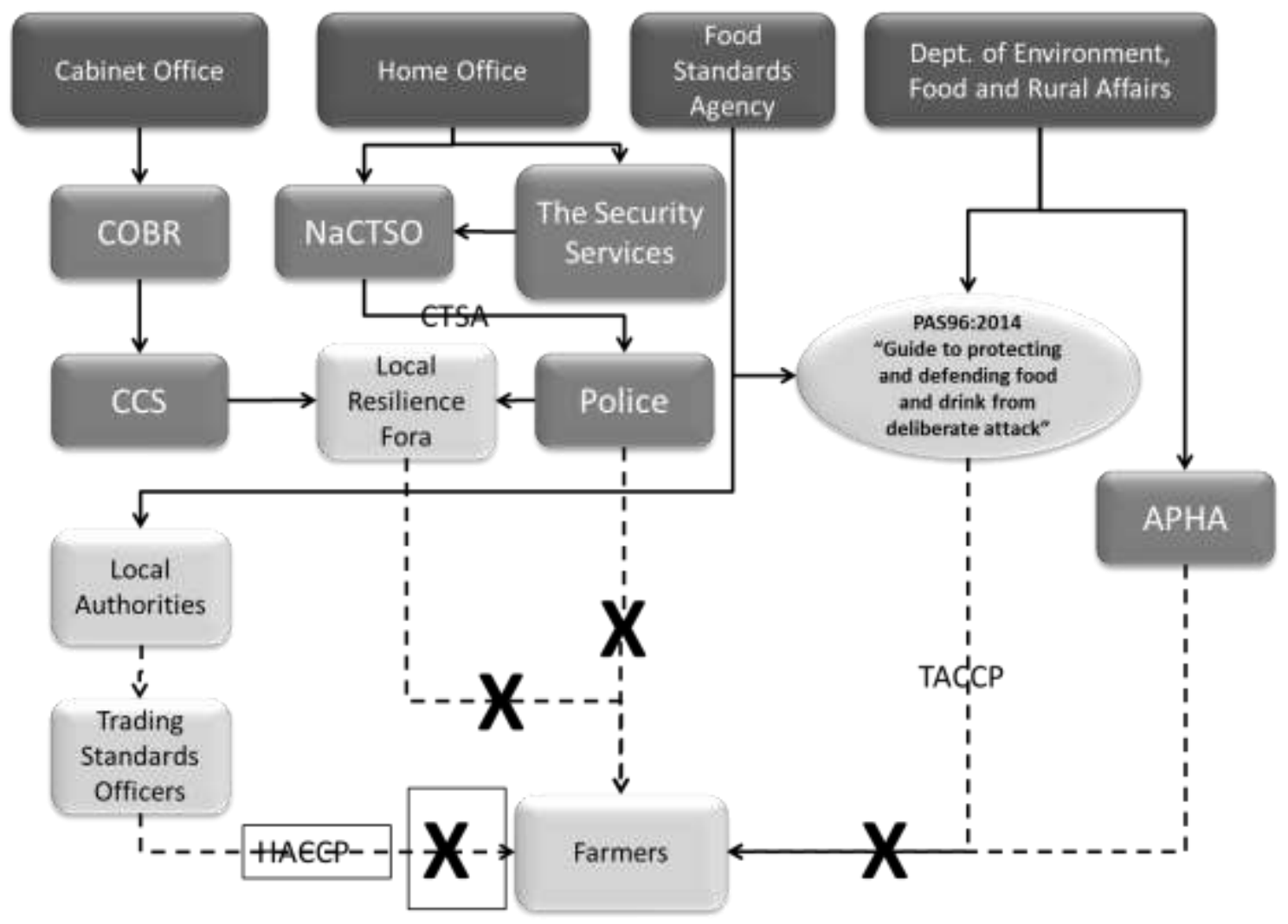

UK policy, even as rebalanced by the new version of PAS96, is intended to ensure that safe, wholesome and affordable food remains available to the public. Crucially though, it is not specifically designed to preserve the UK farming industry or to protect dependent farming/rural communities. It is founded on multiple trade links required to provide alternative sources of food in a crisis. This requires the establishment of international trade connections in order to backfill temporary production shortfalls (Kirwan \& Maye, 2013, p91) but seemingly ignores that such a strategy can actually increase the number of possible vectors of attack.

The large crosses in Figure 6 indicate the perceived weakness of the UK approach resulting from a lack of effective linkage to upstream primary producers. The four sources of information that should be reaching the primary producers are:

- food safety (through local trading standards)

- business resilience (through local resilience networks),

- $\quad$ security advice (from the local police force and associated CTSA)

- biosecurity advice (from DEFRAs Animal \& Plant Heath Agency).

Thus there should therefore be no shortage of data and advice reaching the UK farming industry, but early indications, from our ongoing UK study, suggests that this is not the case.

\section{The RoK model}

The focus on food terrorism is a relatively recent development in RoK and the legislative framework is therefore at an early stage of development. Discussions predominantly reflect the national 
security perspective, as fake or adulterated food products have become a serious social and political issue. However, no proactive measures were proposed to counter food or agroterrorism when the new structure for emergency responses was published recently by the Ministry of Food and Drug Safety (MFDS) (MFDS, 2015). Rather, the RoK governmental approach to food terrorism has evolved around a set of emergency responses which can be applied only once terrorist activity occurs (Ryu, Lee, Song, \& Yoo, 2015).

This does not mean that agroterrorism is being ignored in RoK. Instead, as in the Australian and UK models, the risk of agroterrorism is mitigated within a broader national framework which addresses all risks to the complete food chain, from upstream to downstream. However, there is no law or regulation that specifically targets agroterrorism in RoK and the new RoK Anti-terrorism Law, established in early 2016, failed to recognise agriculture as a possible area for terrorist activity. A framework has therefore not yet been formulated for risk management to prevent or mitigate agroterrorism, or to provide emergency responses to it.

Echoing the UK model, the current RoK national framework prioritises the provision of food safety and public health rather than the protection of agriculture. Accordingly, Figure 7 outlines how RoK government agencies regulate and manage food production and supply, based on a range of relevant, existing RoK laws ${ }^{2}$. These main legislative concerns are based on a consumer-oriented perspective that foods must be safe to eat, and are produced to a high-quality standard (kuk-san). This policy therefore, as with the UK, does not address the macroeconomic and social impact of agroterrorism.

\footnotetext{
${ }^{2}$ Including: Food Safety Law, Law for the Quality Management of Agriculture and Fishery Producers, Food Sanitation Law, Livestock Products Sanitary Control law
} 


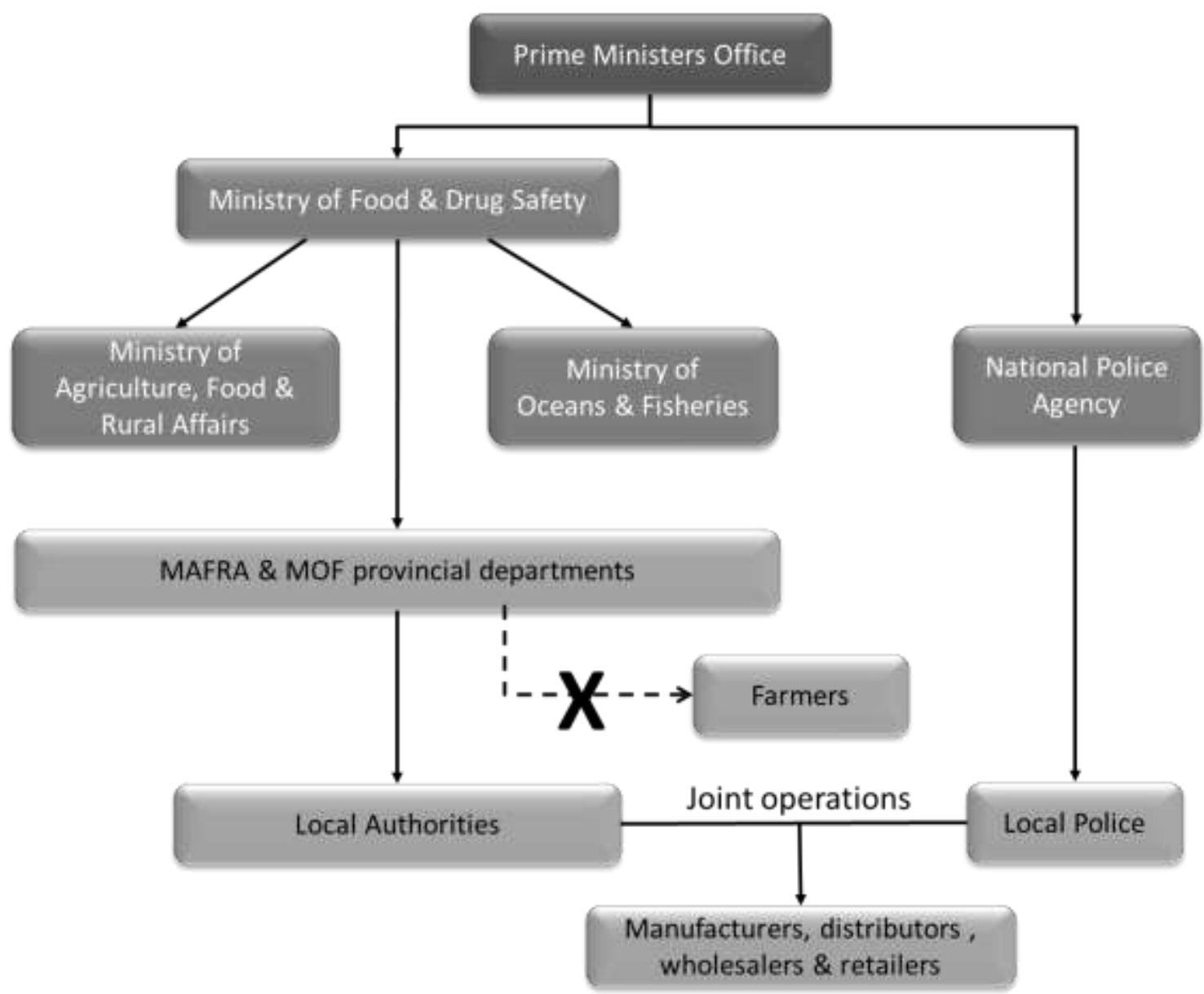

MFDS is the lead government department for food safety in RoK, working with the Ministry of Agriculture, Food and Rural Affairs (MAFRA) and the Ministry of Oceans and Fisheries (MOF) to set food safety agendas and establish regulations at a central strategic level.

Provincial departments of MFDS, MAFRA and MOF assure food safety at an operational level. These departments coordinate and engage in field operations. For example, Central Investigation Units in provincial level departments of the MFDS investigate food safety cases, concentrating on major cases that may bring a significant social impact. Additionally, MFDS provincial level departments run some fifteen "imported food inspection stations" at points of entry to monitor food products from overseas.

At the tactical level, in a similar way to the UK model, the majority of regulatory activities are carried out by "special judicial food police officers", embedded in local authorities but operating under the guidance of provincial departments of the Ministries. However, one problem with this organisational approach is that there is duplication of effort and responsibility with local police officers (i.e. investigators) working for the National Police Agency (NPA) with identical authority to the special food police (Nam, 2014). This duplication has arisen because of the governmental drive on food safety and the fact that NPA has more available resources. However, the result is potential discord between MFDS and NPA due to differing chains of command. To avoid this, the Prime Minister's 
Office initiated intergovernmental joint operations in early 2013 (The Prime Minister's Office, 2013), but there is little indication of how successful these joint operations are.

Again, echoing the UK model, the emphasis in RoK is on downstream security, with MFDS, MAFRA and MOF policies and regulations not yet encompassing the upstream, primary production part of the food chain (The Prime Minister's Office, 2013). Statistics show that of some 63,000 cases investigated nationally from 2013 to the first half of 2015, the majority of arrested people were manufacturers, distributors, or sellers of adulterated food products (Policy briefing, 2015). Safety inspections on farms and associated facilities, or information sharing with farmers, are rarely if ever performed. Currently in RoK, there is no policy of engagement with primary producers, and no education or awareness programs exist.

\section{Conclusions and further research}

Our headline finding on the RoK approach to agroterrorism is that it perhaps resembles, too closely, that of the UK. However, there are better models available internationally in terms of strategy, policy and organisational architectures. Any preventative approach to management of the agroterrorism risk should therefore now be considered objectively, and internationally, and should involve researchers, rather than being developed from the current RoK model. This in turn requires an understanding of risk perceptions and motivations across the various upstream supply stakeholders, and those that are required to respond to agroterrorism incidents, including:

- Farmers (farm workers, agronomists etc.)

- Contiguous trades (feed \& chemical suppliers, wholesalers, etc.)

- Regulators (MFDS, MAFRA \& MOF staff at central and provincial levels)

- Security advisors (Special and National Police, Insurance representatives, etc.)

- First responders (Private and State veterinarians and phytologists, Police, Local Authority contingency planners, etc.).

The working assumption underlying this type of research, which we are currently carrying out in the UK, would be that the more resources are devoted by a society to countering a risk, the higher must be the public perception of that risk (Willis, 2007, p597). We feel that an exploration of variations in risk perception and current practices in regard to agroterrorism, along with the comparative examples of alternative approaches, may assist in shaping future RoK strategy, policy and organisation. 


\section{References}

Beck, U. (1992) Risk Society. Towards a New Modernity. London. Sage Publications Ltd

Borodzicz, E. (2005) Risk, Crisis \& Security Management. Chichester. John Wiley \& Sons Ltd.

Boycott, R. (2008, June 7th) Nine meals from anarchy - how Britain is facing a very real food crisis. Mail Online. Retrieved from http://www.dailymail.co.uk/news/article-1024833/Nine-meals-anarchy-Britain-facing-real-food-crisis.html

British Standards Institute (2014) PAS96:2014. Guide to protecting and defending food and drink from deliberate attack. London. BSI

Byrne, R. (2009) Agro-terrorism and bio-security, threat, response and industry communication. Nuffield Farming Conference, 30-31 October. Retrieved from http://www.openfields.org.uk/Library/content/Detail.aspx?ctID=MzFjODImMDItNDc4My00N2YxLTk OYjEtYzA1ZWIOMmY2ZDJm\&rID=NjU2\&sID=MQ==\&bckToL=VHJ1ZQ==\&qcf=\&ph=VHJ1ZQ==\&AspxA utoDetectCookieSupport=1

Chalk, P.(2004) Hitting America's Soft Underbelly. The Potential Threat of Deliberate Biological Attacks against the U.S. Agricultural and Food Industry. Santa Monica, USA. RAND National Defense Research Institute.

Foxell, J.W jr (2001) Current Trends in Agroterrorism (Antilivestock, Anticrop, and Antisoil Bioagricultural Terrorism) and Their Potential Impact on Food Security. Studies in Conflict \& Terrorism, 24. pp107-129.

GAO (2013) United States Government Accountability Office Report to Congressional Requesters: An Overall Strategy Is Needed to Strengthen Disease Surveillance in Livestock and Poultry. GAO-13-424. Author

Golikov, A. (2009) Modern Agricultural Biotechnology and National Security, Security Index: A Russian Journal on International Security, 15:3-4, pp135-140, doi: 10.1080/19934270.2009.9756618

Hinrichs, C. (2013) Regionalizing food security? Imperatives, intersections and contestations in a post-9/11 world. Journal of Rural Studies, 29 pp7-18

Jung Min-ho (2014) Dongush Food CEO accused of cereal fraud. Korea Times. Retrieved from: http://www.koreatimes.co.kr/www/news/nation/2014/11/116 168610.html

Kim, Jae-won (2013) Gov't fails to calm down worries over food safety. Korea Times. Retrieved from: http://www.koreatimes.co.kr/www/news/issues/2013/09/139 142526.html

Kirwan, J. \& Maye, D. (2013) Food security framings within the UK and the integration of local food systems. Journal of Rural Studies. 29. pp91-100

Kosal, M. \& Anderson, D. (2004) An unaddressed issue of agricultural terrorism: A case study on feed security. Journal of Animal Science, 82. pp3394-3400 
Mårtensson, P.-Å., Hedström, L., Sundelius, B., Skiby, J. E., Elbers, A., \& Knutsson, R. (2013).

Actionable Knowledge and Strategic Decision Making for Bio- and Agroterrorism Threats: Building a Collaborative Early Warning Culture. Biosecurity and Bioterrorism: Biodefense Strategy, Practice, and Science, 11(S1), S46-S54. http://doi.org/10.1089/bsp.2013.0039

Ministry of Food and Drug Safety. (2015). A Manual on Emergency Responses to Food Terrorism.

Nam, J. (2014) Effective Operation of Food Special Judicial Police System for Suppressing Food Related Crime. Journal of Korean Criminology. 8(1). 101-131

Nganje, W., Wilson, W. \& Nolan, J. (2004) Agro-terrorism and the Grain Handling Systems in Canada and the United States. Current Agriculture, Food \& Resource Issues, 5, pp. 148-159

O'Malley, P. (2004) Risk, Uncertainty and Government, New York: Glasshouse.

O'Shea, P. (2015) Dodgy dumplings and lethal liver: risk, food terrorism, and Sino-Japanese relations, The Pacific Review, 28:2, 303-321 http://dx.doi.org/10.1080/09512748.2014.995128

Peck, H.(2006) Resilience in the Food Chain: A Study of Business Continuity Management in the Food and Drink Industry. Final Report to the Department for Environment, Food and Rural Affairs.

Retrieved from Chartered Institute of Purchase \& Supply website:

http://www.cips.org/Documents/Resources/Research/Defra\%20report\%20-

\%20Resiliance\%20in\%20the\%20Food\%20Chain.pdf

Policy briefing. (2015). Reduced four evils, More Safe South Korea. Retrieved from

http://safe.korea.kr/news/newsView.do?sectld=05\&newsld=148807427\&pagelndex=

Prime Minister's Office. (2013) A Report from Food Safety Policy Committee. [Press release].

Retrieved from:

http://pmo.go.kr/pmo/news/news01.jsp?mode=view\&article no=48587\&board wrapper=\%2Fpmo \%2Fnews\%2Fnews01.jsp\&pager.offset=0\&search:search key:search=article title\&search:search val :search=\%25BA\%25D2\%25B7\%25AE\%25BD\%25C4\%25C7\%25B0\&board no=6

Ryu, S., Lee, J., Song, E. \& Yoo, H. (2016) A Review of Response Systems to Food Terrorism in the US: Implications for South Korea. Journal of safety and crisis management. 12(2). 69-78 [Korean language only]

Stern, J. (2003) Dreaded Risks and the Control of Biological Weapons. International Security. Volume 27. Number 3. pp89-123

Ungerer, C. \& Rogers, D. (2006): The Threat of Agroterrorism to Australia: A Preliminary Assessment, Studies in Conflict \& Terrorism, 29:2, pp147-163.

Wheelis, M., Casagrande, R. \& Madden, L.V. (2002) Biological Attack on Agriculture: Low tech, Highimpact Bioterrorism. BioScience Volume 52, Number 7. pp569- 576

Willis, H. (2007) Guiding Resource Allocations Based on Terrorism Risk. Published Articles \& Papers.

Paper 28. Retrieved from

http://research.create.usc.edu/cgi/viewcontent.cgi?article=1062\&context=published papers 
World Health Organisation (2002) Terrorist threats to food: guidance for establishing and strengthening prevention and response systems. Geneva. Author 